\title{
Molecular Survey of Anaplasmataceae Agents and Coxiellaceae in Non-Hematophagous Bats and Associated Ectoparasites from Brazil
}

\author{
Priscila Ikeda ${ }^{1}$ D, Jaire Marinho Torres ${ }^{2}$, Ana Julia Vidal Placa ${ }^{1}$, Victória Valente Califre de Mello ${ }^{1}$, \\ Elizabete Captivo Lourenço $^{3}$, Heitor Miraglia Herrera ${ }^{2}$ (D) Carina Elisei de Oliveira ${ }^{2}$ (D), Claudia Hemsley ${ }^{4}$ (D), \\ Richard W. Titball ${ }^{4}$, Rosangela Zacarias Machado ${ }^{1}$ and Marcos Rogério André ${ }^{1, *(D)}$
}

1 Laboratório de Imunoparasitologia, Departamento de Patologia, Reprodução e Saúde Única, Universidade Estadual "Júlio de Mesquita Filho", Jaboticabal 14884-900, São Paulo, Brazil; priscila.ikeda@unesp.br or prikeda@gmail.com (P.I.); anajuliaplaca@hotmail.com (A.J.V.P.); vick_vvc@hotmail.com (V.V.C.d.M.); rz.machado@unesp.br (R.Z.M.)

2 Laboratório de Biologia Parasitária, Programa de Pós-Graduação em Biotecnologia, Universidade Católica Dom Bosco, Campo Grande 79117-900, Mato Grosso do Sul, Brazil; jairemarinho@hotmail.com (J.M.T.); herrera@ucdb.br (H.M.H.); carinaelisei@ucdb.br (C.E.d.O.)

3 Laboratório de Ecologia de Mamíferos, Universidade do Estado do Rio de Janeiro, Rio de Janeiro 20550-013, Rio de Janeiro, Brazil; beteclouren1205@yahoo.com.br

check for updates

Citation: Ikeda, P.; Torres, J.M.;

Placa, A.J.V.; Mello, V.V.C.d.; Lourenço, E.C.; Herrera, H.M.; Oliveira, C.E.d.; Hemsley, C.; Titball, R.W.; Machado, R.Z.; et al. Molecular Survey of Anaplasmataceae Agents and Coxiellaceae in

Non-Hematophagous Bats and Associated Ectoparasites from Brazil. Parasitologia 2021, 1, 197-209. https://doi.org/10.3390/ parasitologia1040021

Academic Editor: Gábor FÖLDVÁRI

Received: 11 August 2021

Accepted: 28 September 2021

Published: 11 October 2021

Publisher's Note: MDPI stays neutral with regard to jurisdictional claims in published maps and institutional affiliations.

Copyright: ( $) 2021$ by the authors. Licensee MDPI, Basel, Switzerland. This article is an open access article distributed under the terms and conditions of the Creative Commons Attribution (CC BY) license (https:// creativecommons.org/licenses/by/ $4.0 /)$.
4 College of Life and Environmental Sciences-Biosciences, University of Exeter, Exeter EX4 4QD, UK; C.Mueller@exeter.ac.uk (C.H.); R.W.Titball@exeter.ac.uk (R.W.T.)

* Correspondence: mr.andre@unesp.br; Tel.: +55-(16)-3209-7302; Fax: +55-(16)-3202-4275

\begin{abstract}
The Anaplasmataceae family (order Rickettsiales) encompasses obligately intracellular bacteria of the genera Anaplasma, Ehrlichia, and Neorickettsia. Together with Coxiella burnetii (Coxiellaceae family, order Legionellales), these bacteria represent important causative agents of diseases in humans and animals. The scarcity of studies that investigated the occurrence of these agents in bats and their associated ectoparasites, emphasizes the need to achieve a better understanding of the role of these animals in the maintenance of such bacteria. Herein, 418 samples (133 blood, 135 spleen, and 150 ectoparasites) are collected from 135 non-hematophagous bats belonging to 12 species in a periurban area of Campo Grande city, Mato Grosso do Sul state, midwestern Brazil. In the results, $1.65 \%$ (7/418), $12.04 \%(50 / 418)$, and $13.63 \%(57 / 418)$ of samples are positive in PCR assays for Anaplasma spp. (16S rRNA gene), Ehrlichia spp. (dsb gene), and Neorickettsia spp. (16S rRNA gene), respectively. Anaplasma spp. and Neorickettsia spp. are detected in one (5.26\%) Ornithodoros hasei tick larva. Ehrlichia spp. is detected in 14\% of bat flies (represented by Megistopoda aranea, Trichobius costalimai, and Strebla hertigi), $6 \%$ of tick larvae (O. hasei), 12\% of Spinturnicidae mites (represented by Periglischrus sp., P. torrealbai, and P. acutisternus), and 38\% of Macronyssidae mites (Steatonyssuss sp.). The obtained sequences are observed to be similar to Anaplasma phagocytophilum (97.42-97.6\% identified), Ehrlichia minasensis (96.73-100\% identified), Neorickettsia risticii (96.7-100\% identified), and Neorickettsia findlayensis (95.07-100\% identified) by BLASTn analyses, and closely related to Ehrlichia ruminantium by phylogenetic analyses based on the gltA gene. No bat samples (blood/spleen) are positive in the qPCR assay for C. burnetii based on the IS1111 gene. The present work shows, for the first time, the occurrence of Anaplasmataceae in bats and associated ectoparasites (ticks, mites, and bat flies) from Brazil.
\end{abstract}

Keywords: Anaplasma spp.; Ehrlichia spp.; Chiroptera; Coxiella burnetii; Neorickettsia spp.

\section{Introduction}

Approximately 20\% of known mammal species belong to the order Chiroptera, which composes the second largest group of mammals in the world [1]. Currently, there are 1400 species described worldwide. From those, 181 bat species are officially registered in 
Brazil and distributed in 68 genera and nine families [2]. Even though bats are considered as important reservoirs, hosts, and sources of infection for various zoonotic agents (mainly viruses [3]), little is known about their role in the maintenance of vector-borne bacteria, such as Ehrlichia spp., Anaplasma spp., Neorickettsia spp., and Coxiella burnetii.

The Anaplasmataceae family (order Rickettsiales) comprises mandatory intracellular agents of veterinary and medical importance. The family comprises the genera Anaplasma, Ehrlichia, Neorickettsia, Neoehrlichia, and Wolbachia [4-6]. Among the most common diseases caused by this group of bacteria, human granulocytic anaplasmosis (HGA) and human granulocytic ehrlichiosis (HME) affect humans and cause similar clinical symptoms that usually start after a tick bite event [7-9].

The main Anaplasmataceae agents associated with animal diseases are Ehrlichia canis and Anaplasma platys, which cause canine monocytic ehrlichiosis and canine cyclic thrombocytopenia; Anaplasma marginale, which causes bovine anaplasmosis; and Neorickettsia risticii, which causes the Potomac horse fever (PHF).

Up to 20 tick species are involved in the transmission of $A$. marginale and A. phagocytophilum; the main tick genera are represented by Ixodes spp. and Haemophysalis spp. (for A. phagocytophilum), Dermacentor spp. (for A. phagocytophilum and A. marginale), and Rhipicephalus spp. and Hyalomma spp. (for A. marginale) $[9,10]$. While E. canis is transmitted by the tropical lineage of Rhipicephalus sanguineus sensu lato [11] and Amblyomma spp., ticks are involved in the transmission of E. ewingii, E. chaffeensis, and E. ruminantum [12,13]. Ehrlichia minasensis has been primarily isolated from Rhipicephalus microplus and naturally infected cattle [5].

Despite being a sister clade to Ehrlichia, 'Candidatus Neoehrlichia spp.' is not recognized as a new genus, mainly due to the difficulty of isolation [14-17]. Additionally, a plethora of uncultured agents was also described in the literature with the 'Candidatus' status [18-29].

Neorickettsia genera encompasses obligatory intracellular bacteria that, differently from the other Anaplasmataceae agents, are endosymbiotic within digeneans and depend on trematodes for their life cycle [30]. Four diseases are related to these agents: Potomac horse fever (PHF) caused by N. risticii; salmon poisoning disease in dogs, which is mainly caused by N. helminthoeca; Elokomin fluke fever (EFF) in canids and bears, which is caused by N. elokominica; Sennetsu fever in humans caused by N. sennetsu agent. Recently, Teymournejad et al. (2020) [31] described a new species of Neorickettsia (i.e., Neorickettsia findlayensis) in Ontario, Canada, causing PHF disease based on serological evidence, whole genome sequencing, and experimental infection of horses. In Brazil, N. risticii was molecularly detected in horses from Rio de Janeiro, which presented with hypoalbuminemia, high levels of creatine kinase, and lactate dehydrogenase [32], as well in equids in the state of Rio Grande do Sul, where outbreaks of equine monocytic ehrlichiosis were reported [33,34].

Studies on the occurrence of Ehrlichia spp. and Anaplasma spp. in bats are scarce. For instance, A. phagocytophilum DNA was already reported in bat fecal samples in France [35] and in Ixodes simplex parasitizing bats in Hungary and Romania [36]. The DNA of A. phagocytophilum and Ehrlichia spp. was found in Pipistrellus pipistrellus and P. kuhlii bats, respectively, in Russia [37]. Ehrlichia spp. was also molecularly detected in bat-related Argas vespertilionis ticks in France [38] and Brachyphylla cavernarum bats in Saint Kitts Island [39]. A. vespertilionis ticks collected from bats in different counties of England were also positive for Ehrlichia/Anaplasma [40]. The detection of these agents in bats and associated ectoparasites in human-shared sites [35,38] contributed to an increased concern about the role of these animals as reservoirs and in the spread of potentially zoonotic diseases.

On the other hand, bats species have been implicated as important hosts for N. risticii. This agent was detected in bat tissues and/or associated trematodes in the USA, Argentina, Egypt, Philippines, and the Netherlands [41-45]. Additionally, this agent was detected in fecal samples collected from a variety of bats from Europe [46].

Coxiella burnetii (order Legionellales), the etiological agent of $\mathrm{Q}$ fever in humans, is a Gram-negative bacterium that parasites monocytes and macrophages [47]. It can be found in feces, milk, urine, and abortion products, such as placenta, where it is possible to find 
a high concentration of the bacteria [48]. This agent can cause abortion and infertility in cattle and goats [49]. In humans, while the acute phase is characterized by hepatitis or, more unusually, pneumonia, the most frequent clinical manifestation in the chronic phase is endocarditis $[47,50]$. This agent was already described in bats and related ectoparasites from Algeria, South Africa, Chile, and Brazil [51-53].

Due to the importance of Anaplasmataceae agents and C. burnetii in animal and human health and the high representativeness of the order Chiroptera in Brazil, the present study aims to molecularly survey these agents in non-hematophagous bats and their ectoparasites sampled in midwestern Brazil.

\section{Results}

A total of 135 bats were captured and DNA samples obtained from 135 spleen tissues, 133 blood, and 150 ectoparasites (including 64 bat flies, 46 Spinturnicidae mites, 21 Macronyssidae mites and 19 tick larvae) were positive in the PCR assays for the endogenous genes (Supplementary Table S1).

All DNA samples obtained from spleen fragments, whole blood samples, and ectoparasites, totaling 418 samples, were negative for Ehrlichia spp. and Anaplasma spp. when tested for the groEL gene by a multiplex real-time PCR. Seven $(1.67 \%)$ out of the 418 samples submitted to the protocol, using conventional nested PCR targeting the $16 \mathrm{~S}$ rRNA gene for Anaplasma spp., were considered positive, presenting a single band with low intensity (Supplementary Table S2). Out of these, three samples were represented by spleen fragments from Platyrrhinus lineatus individuals, three from blood samples of Phyllostomus discolor specimens, and one from the Ornithodoros hasei tick larvae, which was collected from a negative $P$. discolor individual. Out of all positive samples, only one amplicon obtained from $O$. hasei was sequenced, due to the low intensity of bands in agarose gel electrophoresis. When analyzed by BLASTn analysis, the obtained sequence (542 bp) showed $97.6 \%$ identity $(100 \%$ query coverage; E-value $=0.0)$ with the $A$. phagocytophilum detected in a deer (Hydropotes inermis) from the Republic of Korea (Accession number: KR611598.1) and 97.42\% of identity with A. phagocytophilum and A. bovis detected in Haemaphysalis longicornis $(100 \%$ of query coverage; E-value $=0.0)$, sampled in South Korea (Accesion numbers: GU046565.1 / GU064901.1).

Out of the seven samples showing positivity in the nested PCR for Anaplasma spp., none showed positivity neither when submitted to quantitative real time PCR (qPCR) for A. phagocytophilum based on the msp-2 gene nor in PCR assays targeting ITS 23S-5S and groEL. On the other hand, one blood sample obtained from a $P$. discolor individual was positive in the PCR targeting the glt $A$ gene and sequenced. However, when tested by BLASTn, the sequence obtained ( $620 \mathrm{bp})$ showed to be similar $(83.15 \%$ of identity) to Ehrlichia sp. identified in a tick from China (KJ410275.1) (100\% of query coverage; E-value $=4 \times 10^{-155}$ ).

Regarding the PCR targeting the $d s b$ gene for Ehrlichia spp., 50 (11.96\%) out of the 418 samples were positive: ten (20\%) blood samples (collected from five Artibeus planirostris, four P. discolor, and one Eptesicus furinalis), eight (16\%) spleen fragments (collected from three A. planirostris, two Artibeus lituratus, two P. lineatus, and one Carollia perspicillata), seven $(14 \%)$ bat flies [namely Megistopoda aranea $(\mathrm{n}=3)$, Trichobius costalimai $(\mathrm{n}=2)$, and Strebla hertigi $(\mathrm{n}=2)]$, three $(6 \%)$ tick larvae $(O$. hasei $)$, six $(12 \%)$ Spinturnicidae mites (three Periglischrus sp., two Periglischrus torrealbai and one Periglischrus acutisternus), and 19 (38\%) Macronyssidae mites (Steatonyssuss sp.). Six animals had more than one positive sample, while animal \#7 (A. planirostris) showed positivity in both spleen and blood samples. All the remaining five individuals were represented by $P$. discolor specimens and showed positivity for blood and/or one or more ectoparasites associated. Out of these positive samples, one bat blood sample, two Spinturnicidae mite samples, and nine Macronyssidae mite samples were chosen for sequencing (Supplementary Table S3). The sample obtained from one Macronyssidae mite (\#75) (353 bp) showed to be 100\% identical to a sequence of E. minasensis detected in R. microplus (MT135771) from Brazil (100\% of query coverage; 
E-value $=0.0$ ). The remaining sequences $(399-416 \mathrm{bp}$ ) were similar (identity ranging from 96.73 to $99.26 \%$ ) to a sequence of E. minasensis detected in Bradypus variegatus (MT212414) from Brazil (query coverage ranging from 99-100\%; E-value $=0.0$ ). None of the 50 Ehrlichia (dsb)-positive samples showed to be positive neither in qPCR protocols for Ehrlichia canis (dsb gene) and E. chaffeensis (vlpt gene) nor in CPCR protocols for Ehrlichia spp. based on the omp-1, sodB, and groEL genes.

Fifty-seven (13.63\%) out of 418 samples were positive in the nested PCR assay for $N$. risticii, based on the 16S rRNA gene: $11(19.3 \%)$ were from animals of the species A. lituratus (five from spleen fragments and six from whole blood), $11(19.3 \%)$ of the species P. lineatus (four from spleen fragments and seven from whole blood), 10 (17.54\%) of the species A. planirostris (six from spleen fragments and four from whole blood), nine (15.79\%) of the species P. discolor (two from spleen fragments and seven from whole blood), four $(7.01 \%)$ of the species $E$. furinalis (one from spleen fragments and three from whole blood), three (5.26\%) of the species C. perspicillata (two from spleen fragments and one from whole blood), two (3.5\%) of the species Molossus molossus (one from spleen fragments and one from whole blood), two (3.5\%) of the species Glossophaga soricina (one from spleen fragments and one from whole blood), and one (1.57\%) positive blood sample of the species Myotis nigricans, Molossops temminckii, Eumops perotis, and Chiroderma villosum. The only ectoparasite sample that was positive for this agent was an O. hasei tick larva collected from a negative specimen of $P$. discolor (Supplementary Table S4). Out of the 34 positive blood samples for the $16 \mathrm{~S}$ rRNA-based PCR assay, 11 (32.35\%) were chosen for sequencing. The samples were chosen for convenience, but in such a way as to represent an individual of each bat species that showed positivity in this protocol. When analyzed by BLASTn, eight sequences (426-524 bp) obtained from blood samples showed similarity (97.9-100\%) with N. risticii (Accession numbers MK760560 and CP001431.1) (100\% of query coverage; E-value $=0.0)$; three sequences obtained from a tick larvae (304 bp), one bat spleen (421 bp) and one bat blood sample (385 bp) was observed to be $95.07-100 \%$ identical to $N$. findlayensis (Accession number MH476282) (100\% of query coverage; E-value $=7 \times 10^{-131}$ to 0.0 ); finally, two sequences obtained from bat blood samples (212-282 bp) were observed to be similar $(96.7-100 \%)$ to $N$. risticii and N. findlayensis (Accession numbers MK580530 and MH476282) $\left(100 \%\right.$ of query coverage; E-value $=1 \times 10^{-143}$ to $\left.1 \times 10^{-96}\right)$. All the positive samples were negative in the additional PCR protocols targeting the $p 51 k D a$, groEL, and near-full 16S rRNA genes.

Moreover, Ehrlichia DNA was detected in $7 / 7$ bat flies, $3 / 3$ ticks, 18/19 Macronyssidae, and $4 / 6$ Spinturnicidae mites, whose bat hosts were negative. The ticks that were positive for Neorickettsia spp. and Anaplasma spp. were also collected from a negative animal.

All the BLASTn results are summarized and presented in the Supplementary Table S5.

A total of 268 DNA samples (133 from whole blood and 135 from spleen fragments) were screened for the presence of $C$. burnetii DNA and none were positive. Unfortunately, the DNA samples from ectoparasites did not yield sufficient volume for this assay.

One phylogenetic tree was constructed based on a $522 \mathrm{bp}$ alignment of the $g l t A$ gene (Figure 1), using the Maximum Likelihood method and TIM3 + F + I + G4 as the evolutive model. The unique sequence obtained from a blood sample from P. discolor (GenBank Accession Number OK338001) was positioned closely to E. ruminantium. The remaining sequences were not further analyzed as the final alignment length was not suitable for robust inferences. 


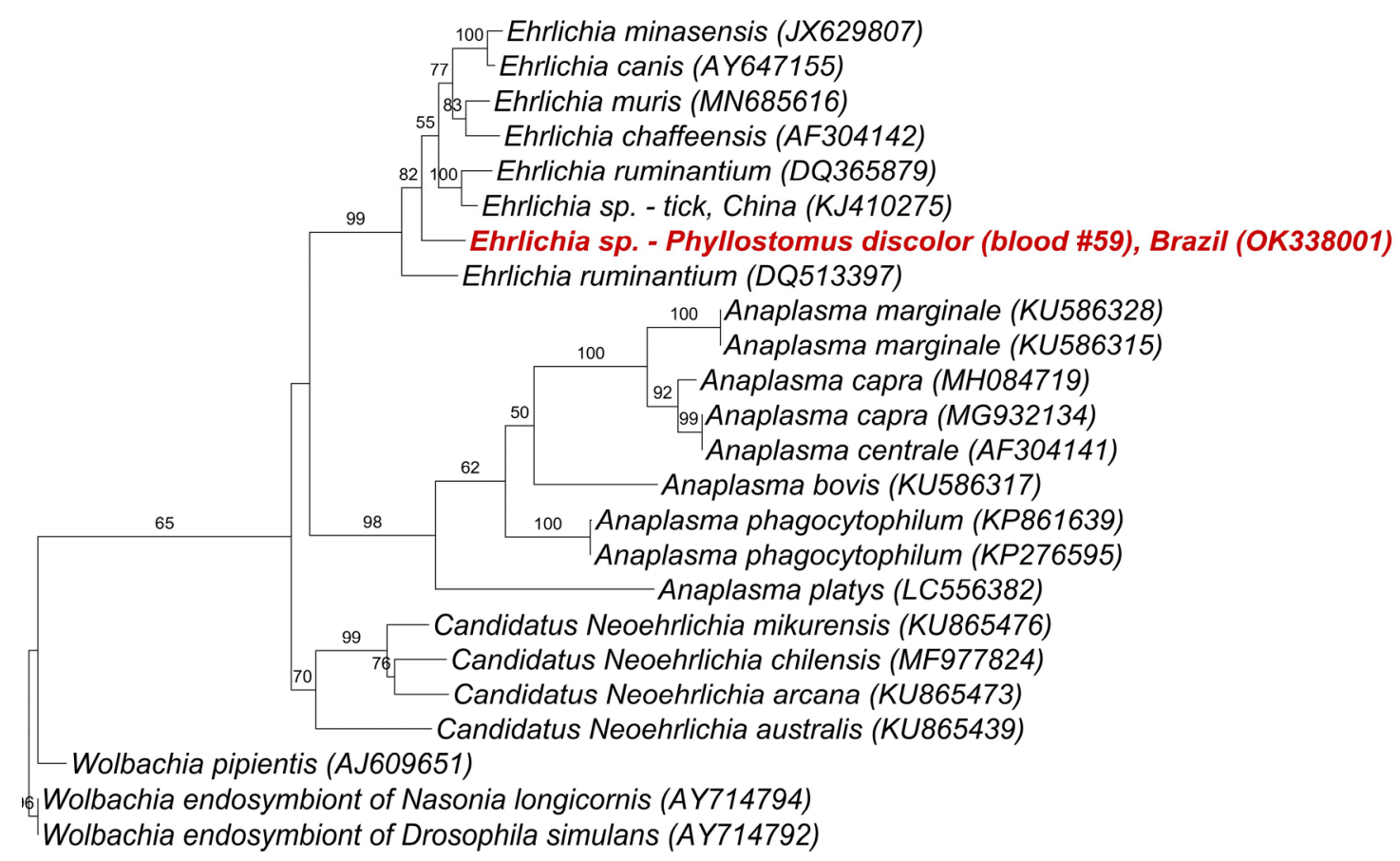

Figure 1. Phylogenetic tree based on an alignment of $522 \mathrm{bp}$ of Ehrlichia gltA gene, using Maximum Likelihood method and $\mathrm{TIM} 3+\mathrm{F}+\mathrm{I}+\mathrm{G} 4$ as evolutive model. Sequence from the present study is highlighted in red. Wolbachia spp. was used as outgroup.

\section{Discussion}

Among all the seven positive samples for Anaplasma spp., only the amplicon obtained from O. hasei tick larva was sequenced, obtaining $97.6 \%$ similarity with A. phagocytophilum, which was previously detected in deer of the species Hydropotes inermis from the Republic of Korea. Previously, the occurrence of A. phagocytophilum was described in $22.6 \%(63 / 278)$ of fecal samples of Rhinolophus hipposideros in France [35], 1.7\% (1/59) of blood samples of Myotis myotis [54] in Poland, 4.3\% (6/138) of I. simplex ticks collected from bats from Hungary and Romania [36], and 14.28\% (1/7) of Nyctalus noctula species from Russia [37]. Despite the high occurrence of $A$. phagocytophilum in bats from France, the remaining abovementioned studies showed low positivity for this agent among bats or associated ectoparasites, corroborating the results found in the present work for Anaplasma spp. (1.67\%; 7/418). Noteworthy, even though sequences similar to A. phagocytophilum have been detected in several wild animals from Brazil, negative results have been reported when a qPCR specific for this agent and based on $m s p-2$ gene was used [6,55]. Together, these findings suggest that a putative new Anaplasma species is circulating among wild animals from Brazil. Indeed, new 'Candidatus Anaplasma spp.', namely 'Candidatus Anaplasma brasiliensis' and 'Candidatus Anaplasma amazonensis' have been recently detected in mammals from the Superorder Xenarthra from Brazil [29]. Future studies aiming at obtaining larger fragments of different molecular markers are needed in order to check the phylogenetic relatedness of bat-associated Anaplasma spp. to these newly described 'Candidatus Anaplasma spp.'.

The unique Anaplasmataceae gltA sequence obtained was observed to be similar to Ehrlichia spp. with low identity obtained when compared to other sequences $(<90 \%)$. The phylogenetic analysis evidenced that the sequence was closely related to E. ruminantium and Ehrlichia spp., detected in a tick from China. Even though there are reports of the occurrence of E. canis, E. ruminantium, and E. muris-like in humans [8], these agents represent a major concern in animal health. E. ruminantium, which is known to cause heartwater or cowdriosis in wild and domestic ruminants, is mainly transmitted by Amblyomma spp. ticks in Africa and the Caribbean [12,56]. Interestingly, a genotype (Strain Jaguar) related to, albeit distantly, called E. ruminantium, was detected in jaguars and in associated ticks (A. triste, 
A. sculptum, and Amblyomma spp.) sampled in Pantanal wetland, in midwestern Brazil, and is based on $r r s$ and $d s b$ sequences [57]. Additionally, a similar genotype (fox-ES-1) was detected in crab-eating foxes (Cerdocyon thous) in southeastern Brazil [58].

Herein, 11.96\% (50/418) of samples were positive in PCR assays for Ehrlichia spp. based on the $d s b$ gene. Out of these positive samples, 35 [70\% (35/50)] were obtained from ectoparasites. In fact, few reports have shown the occurrence of Ehrlichia sp. in bats and associated ectoparasites. Socolosvich et al. (2012) [38] detected Ehrlichia DNA in A. vespertilionis, an Argasidae species often associated with bats and humans in places cohabitated by them. In Saint Kitts Island, Reeves et al. (2016) [39] found 16\% (4/25) of positivity for Ehrlichia spp. in blood samples collected from bats (Brachyphylla caverum). The obtained sequences showed 95\% identity with Ehrlichia sp. detected in ticks collected from mammals from Asia. More recently, Lv et al. (2018) [40] detected DNA of Ehrlichia/Anaplasma in five out of 120 A. vespertilionis ticks collected from three P. pipistrellus bats in England. Zabashta et al. (2019) [37] also detected Ehrlichia DNA (without sequencing) in P. pipistrellus and P. kuhlii bats from Russia.

Interestingly, the obtained Ehrlichia dsb sequences were observed to be related to $E$. minasensis. This agent has been described in cattle and R. microplus from Brazil $[5,59,60]$, potentially causing disease in cattle [61]. Recently, Ehrlichia dsb genotypes closely related to E. minasensis were detected in Xenarthra mammals in Brazil [29]. These results suggest that E. minasensis may infect a broader range of hosts than previously recognized.

Even though the multiplex qPCR assay, used herein for detecting a fragment of groEL gene for Ehrlichia and Anaplasma species with high sensitivity and specificicity [62], was originally designed for amplifying DNA from the main Ehrlichia (namely E. canis, E. chaffeensis, E. muris, and Ehrlichia sp., Anan strain/IOE agent), and Anaplasma (namely A. phagocytophilum, A. platys, A. marginale, A. centrale, A. ovis, and A. bovis) species. Considering that bats and associated ectoparasites likely harbor DNA of genetically diverse Ehrlichia and Anaplasma species, the used qPCR assays, based on the groEL gene, which is less conserved than $16 \mathrm{~S}$ rRNA gene, were not able to catch these putative new genotypes/species of Ehrlichia and Anaplasma. This incongruence between the results of the groEL-based multiplex qPCR and $16 \mathrm{~S}$ rRNA-based cPCR assays was already reported previously $[29,62,63]$, when working on the molecular detection of Ehrlichia and Anaplasma in biological samples from wild animals from Brazil, which emphasizes the occurrence of putative new genotypes or even species of Anaplasmataceae in the Brazilian wildlife.

High prevalence of N. risticii in bats has been reported in the USA (e.g., $60 \%(3 / 5)$ in Myotis yumanensis, 44.7\% (17/38) in Myotis lucifugus, 40\% (6/15) in Eptescicus fuscus) $[41,42]$ and in the Netherlands (100\% (4/4) in Myotis dasycneme) [46]. In South America, while the present work found $38.51 \%(52 / 135)$ of occurrence for Neorickettsia spp., Ciccutin et al. [43,44] found 8.2\% (5/61)-10\% (3/30) prevalence of N. risticii in Tadarida brasiliensis sampled in Argentina.

$N$. risticii is known to cause the equine monocytic neorickettsiosis (formerly ehrlichiosis) or Potomac horse fever (PHF) in horses [64], being reported primarily in the USA. The main transmission route occurs through ingestion of aquatic snails that act as intermediary hosts for Neorickettsia-infected digenean trematodes [65,66]. Recently, Paulino et al. (2020) [32] detected N. risticii (16S rRNA) DNA in horse blood samples, sampled in Rio de Janeiro, Brazil. Previously, an outbreak of equine monocytic neorickettsiosis has also been reported in the state of Rio Grande do Sul [33]. In addition, N. risticii DNA has been detected in Heleobia snails (H. piscium, H. parchappei, H. davisi) collected in the state of Rio Grande do Sul [34]. Recently, N. findlayensis was described as a new species that also causes a disease similar to PHF [31].

It is known that bats not only act as a host for $\mathrm{N}$. risticii-infected trematodes but also as a possible natural reservoir for $N$. risticii, as this agent has been detected in tissues (e.g., intestine, lung, liver, and spleen) of naturally infected bats [41-44]. The detection of Neorickettsia spp. in digenean trematodes found parasitizing bats [45] emphasized their contribution to the maintenance of these agents. In addition, vertical transmission of N. risticii from 
adult trematodes (Acanthatrium oregonense) to eggs was evidenced when these helminthes were collected from E. fuscus bats in the USA [42]. In Europe, Hornok et al. (2018) [46] found $2.96 \%(4 / 135)$ positivity for $N$. risticii in $M$. dasycneme individuals sampled in the Netherlands. Future studies should be performed in order to investigate the bat-associated trematodes involved in the epidemiology of $N$. risticii in Brazil. Considering that it was not possible to confirm which Neorickettsia species is circulating among the sampled bats, epidemiological studies should be performed in an attempt to establish a possible correlation between infected bats and the occurrence or neorickettsiosis in horses in Brazil.

Herein, Ehrlichia DNA was detected in $14 \%$ bat flies (M. aranea, T. costalimai, and S. hertigi), 6\% tick larvae (O. hasei), 12\% Spinturnicidae mites, and 38\% Macronyssidae mites. Out of those, Ehrlichia DNA was detected in seven bat flies, three ticks, 18 Macronyssidae and four Spinturnicidae mites, collected from bats that showed to be negative in the PCR assay for this agent. Similarly, the O. hasei tick larva that was positive for Neorickettsia spp. was collected from a specimen of $P$. discolor that showed to be negative for this agent. Moreover, DNA of Anaplasma spp. was detected in $O$. hasei larvae collected from a negative P. discolor individual. Considering the impossibility that the larval stage had ever fed on another animal, the transovarial transmission of bat-associated Anaplasma spp. cannot be rule out. Indeed, while the transovarial transmission of non-pathogenic A. phagocytophilum variants has been already reported in Dermacentor albipictus ticks, transovarial transmission of Ehrlichia spp. has not been proved [8,67]. Also, a possible explanation for these results might rely on a false-negative result with the bat samples (blood or spleen). It may occur due to the higher concentration of the host blood meal in the arthropod digestive tract, which may had increased the chances of detection of Ehrlichia DNA in the ectoparasite sample, as previously reported [68]. Lastly, the efficiency of the PCR assays should also be considered in this case. Nevertheless, the real role of ticks, mites, and bat flies in the transmission of Anaplasmataceae agents among bats should be further investigated.

Despite the lack of positivity for C. burnetii among bats sampled in the present work, this agent has already been reported in 3.4\% (4/119) of bats in the Atlantic Forest in the states of Santa Catarina and Rio de Janeiro, Brazil, by conventional PCR and nested PCR assays based on the IS1111 gene in which the positive animals belonged to the species $A$. lituratus (3/4) and A. fimbriatus (1/4) [53]. Furthermore, this agent was detected in $15.8 \%$ (3/19) of I. verpertilionis ticks collected from bats in northeastern Algeria using real-time PCR based on the IS1111 marker [51]. More recently, C. burnetii was detected in five individuals (9\%) of T. brasiliensis from Chile, also using a qPCR targeting the IS1111 gene [69]. However, it is worth mentioning that Coxiella-like endosymbionts are commonly found in ticks and, recently, it was shown that endosymbionts and C. burnetii are closely related [70]. The authors also suggested that the lineages might have evolved independently. Therefore, the possible participation of bats and specially their ectoparasites in the transmission of C. burnetii should be further investigated, since molecular and serological evidence of infection by C. burnetii has been reported in humans from Brazil [71-73].

In conclusion, the present work shows, for the first time, the occurrence of Ehrlichia spp. related to E. minasensis, E. ruminantium, and Anaplasma spp., similar to A. phagocytophilum and Neorickettsia spp., in non-hematophagous bats and associated ectoparasites (ticks, mites, and bat flies) from Brazil.

\section{Material and Methods}

A total of 135 spleen, 133 blood and 150 ectoparasites samples were collected from 135 non-hematophagous bats captured and sampled in two different sites ("Centro de Educação Ambiental Polonês" and "Centro de Educação Ambiental Florestinha") situated in the Campo Grande city, Mato Grosso do Sul state, Brazil as described elsewhere [74]. The bats' capture occurred quarterly between June 2017 and March 2018.

The DNA was purified from 50-200 $\mu \mathrm{L}$ blood samples using the Illustra Blood Mini Kit (GE Healthcare ${ }^{\circledR}$, Chicago, IL, USA) and from $10 \mathrm{mg}$ of each bat spleen tissue and ectoparasites using the Illustra Tissue Mini Kit (GE Healthcare ${ }^{\circledR}$ ), according to manufac- 
turer's instructions. The DNA concentration and absorbance ratio (260/280 nm) were measured using a spectrophotometer (Nanodrop, Thermo Scientific, Waltham, MA, USA). To check the quality of the extracted DNA and avoid the presence of PCR inhibitors, each spleen and blood DNA extracted was tested by a conventional PCR targeting the mammal gapdh (Glyceraldehyde 3-phosphate dehydrogenase) gene [75]. For the ectoparasites collected from the animals, two different conventional PCR protocols were used. While a PCR protocol based on cytochrome c oxidase subunit I (cox-1) gene [76] was used for DNA samples obtained from bat flies and mites, a protocol based on the 16S rRNA gene [77] was used for DNA samples obtained from tick larvae.

Bat blood and spleen samples positive for the mammals' endogenous gene (gapdh) PCR protocol were submitted to PCR assays for Anaplasmataceae agents and C. burnetii. Ectoparasites positive in PCR assays based on cox-1 and 16S rRNA genes were only submitted to PCR assays for Anaplasmataceae agents, due to the low volume of DNA obtained.

For Anaplasmataceae agents, quantitative real-time (q), nested (n), and conventional (c) PCR screening protocols were performed for Anaplasma spp. and Ehrlichia spp. A multiplex qPCR for Anaplasma spp. and Ehrlichia spp. based on the groEL gene was performed as previously described [62]. Additionally, a nested PCR for Anaplasma spp., based on the 16S rRNA gene [78] and a conventional PCR for Ehrlichia spp., based on the $d s b$ gene [79], were also used as screening protocols. All the positive samples found in the above-mentioned protocols were submitted to qPCR assays for E. canis based on the $d s b$ gene [79], E. chaffeensis based on the vlpt gene [80], and A. phagocytophilum based on msp-2 gene [81]. Conventional and nested PCR assays, based on groEL [17,82], gltA [16], $\operatorname{sodB}$ [83], and omp-1 [84] genes as well as based on the intergenic region ITS 23S-5S [85], were performed for molecular characterization.

For molecular detection of N. risticii, DNA samples were submitted to a nested PCR based on the 16S rRNA gene, as previously described [86]. Additionally, the positive samples for the 16S rRNA were submitted to PCR assays targeting the nearly full-length $16 \mathrm{~S}$ rRNA [87], $p 51 k D a$, and groEL [43,63,88] genes.

A quantitative real-time PCR targeting the repetitive element IS1111 was used for C. burnetii detection, as previously described [89].

As positive controls for the PCR assays, DNA samples from A. phagocytophilum and $N$. risticii kindly provided by Professor John Stephen Dumler (Uniformed Services University of the Health Sciences, Bethesda, MD, USA), and the E. canis Jaboticabal-strain (maintained in DH82 cell culture) were used. The C. burnetii DNA positive control was kindly provided by Professor Dr. Renato Arruda Mortara (Universidade Federal de São Paulo, SP, Brazil).

Firstly, the obtained sequences were submitted to a screening test using the Bioedit version 7.0.5.3 [90] to evaluate the electropherogram quality and to obtain consensus sequences from the alignment of the sense and antisense sequences. The BLAST program [91] was used to analyze the sequences of nucleotides (BLASTn), aiming to compare with sequences from an international database (GenBank) [92]. The consensus sequences obtained in the present study and those retrieved from GenBank were aligned using the ClustalW software [93] via Bioedit version 7.0.5.3 [89]. Phylogenetic inferences were based on Maximum Likelihood (ML). The best evolutionary model was selected by ModelFinder [94] and the trees were constructed using IQTree web server [95] with ultrafast Bootstrap of 1000 replicates [96]. All the trees were examined in Treegraph 2.0 beta software [97].

Supplementary Materials: The following are available online at https:/ / www.mdpi.com/article/10 .3390/parasitologia1040021/s1, Table S1: Description of the 418 samples (spleen, blood or ectoparasites) collected from bats in Campo Grande, Mato Grosso do Sul, Brazil, and used in the present work for molecular screening of Anaplasmataceae agents and Coxiella burnetii, Table S2: Bat samples positive for Anaplasma spp. according to PCR assays targeting five different molecular markers, Table S3: Bat samples positive for Ehrlichia spp. according to PCR assays targeting six different molecular markers, Table S4: Bat samples positive for Neorickettsia spp. according to PCR assays targeting three different 
molecular markers, Table S5: BLASTn results obtained after sequencing of amplicons obtained from PCR assays for Ehrlichia spp., Anaplasma spp. and Neorickettsia spp.

Author Contributions: Conceptualization, M.R.A., P.I. and R.Z.M.; methodology, P.I., J.M.T., A.J.V.P., V.V.C.d.M. and E.C.L.; sample analysis, P.I., A.J.V.P. and V.V.C.d.M.; resources, M.R.A., R.Z.M., H.M.H., C.H., R.W.T. and C.E.d.O.; data curation, P.I., J.M.T. and E.C.L.; writing-original draft preparation, P.I., M.R.A., A.J.V.P. and V.V.C.d.M.; supervision, M.R.A., H.M.H., C.E.d.O. and R.Z.M.; project administration, P.I., V.V.C.d.M. and M.R.A.; funding acquisition, M.R.A., H.M.H., C.H., R.W.T. and R.Z.M. All authors have read and agreed to the published version of the manuscript.

Funding: This research was funded by FAPESP (Foundation for Research Support of the State of São Paulo-Process \#2018/02753-0 and \#2017/14124-4); FUNDECT (Foundation for Support to the Development of Education, Science and Technology of the State of Mato Grosso do Sul, Case 59/300.187/2016); CNPq (National Council for Scientific and Technological Development) for the Productivity Grant to MRA (CNPq Process \#302420/2017-7) and HMH (CNPq Process \#308768/20175); PI received scholarship from FAPESP (Process \#2017/14124-4) and ECL received scholarship from FAPERJ (E-26/201.806/2020). The funders had no role in the design of the study; in the collection, analyses, or interpretation of data; in the writing of the manuscript, or in the decision to publish the results.

Institutional Review Board Statement: All experiments were approved by the "Instituto Chico Mendes de Biodiversidade" (ICMBio, Federal Institution of Brazil) (SISBIO 57450-1) and by the Ethics Committee of the School of Agricultural and Veterinary Sciences-UNESP (CEUA FCAV/UNESP 010050/17).

Informed Consent Statement: Not applicable.

Data Availability Statement: GenBank number Accession MZ220334-46 for 16SrRNA Neorickettsia spp. sequences; MZ220347 for 16SrRNA Anaplasma spp. sequence; OK338001 for the gltA Ehrlichia sp. sequence; OK345019-30 for the dsb Ehrlichia spp. sequences.

Acknowledgments: The authors are especially thankful to the InsanaHuna Research Group (www. insanahuna.com) for the fieldwork support.

Conflicts of Interest: The authors declare no conflict of interest.

\section{References}

1. Schipper, J.; Chanson, J.S.; Chiozza, F.; Cox, N.A.; Hoffmann, M.; Katariya, V.; Lamoreux, J.; Rodrigues, A.S.; Stuart, S.N.; Temple, H.J.; et al. The status of the world's land and marine mammals: Diversity, threat, and knowledge. Science 2008, 322, 225-230. [CrossRef] [PubMed]

2. Garbino, G.S.T.; Gregorin, R.; Lima, I.P.; Loureiro, L.; Moras, L.M.; Moratelli, R.; Nogueira, M.R.; Pavan, A.C.; Tavares, V.C.; do Nascimento, M.C.; et al. Updated Checklist of Brazilian Bats: Versão 2020. Comitê da Lista de Morcegos do Brasil—CLMB. Sociedade Brasileira para o Estudo de Quirópteros (Sbeq). Available online: https:/ /www.sbeq.net/lista-de-especies (accessed on 6 July 2021).

3. Mühldorfer, K. Bats and Bacterial Pathogens: A Review. Zoonoses Public Health 2013, 60, 93-103. [CrossRef] [PubMed]

4. Dumler, J.S.; Barbet, A.F.; Bekker, C.P.; Dasch, G.A.; Palmer, G.H.; Ray, S.C.; Rikihisa, Y.; Rurangirwa, F.R. Reorganization of genera in the families Rickettsiaceae and Anaplasmataceae in the order Rickettsiales: Unification of some species of Ehrlichia with Anaplasma, Cowdria with Ehrlichia and Ehrlichia with Neorickettsia, descriptions of six new species combinations and designation of Ehrlichia equi and 'HGE agent' as subjective synonyms of Ehrlichia phagocytophila. Int. J. Syst. Evol. Microbiol. 2001, 51 Pt 6, 2145-2165. [CrossRef] [PubMed]

5. Cabezas-Cruz, A.; Zweygarth, E.; Vancová, M.; Broniszewska, M.; Grubhoffer, L.; Passos, L.M.F.; Ribeiro, M.F.B.; Alberdi, P.; de la Fuente, J. Ehrlichia minasensis sp. nov., isolated from the tick Rhipicephalus microplus. Int. J. Syst. Evol. Microbiol. 2016, 66, 1426-1430. [CrossRef] [PubMed]

6. André, M.R. Diversity of Anaplasma and Ehrlichia/Neoehrlichia Agents in Terrestrial Wild Carnivores Worldwide: Implications for Human and Domestic Animal Health and Wildlife Conservation. Front. Vet. Sci. 2018, 5, 293. [CrossRef]

7. Bakken, J.S.; Dumler, J.S. Clinical diagnosis and treatment of human granulocytotropic anaplasmosis. Ann. N. Y. Acad. Sci. 2006, 1078, 236-247. [CrossRef]

8. Ismail, N.; McBride, J.W. Tick-Borne Emerging Infections: Ehrlichiosis and Anaplasmosis. Clin. Lab. Med. 2017, 37, 317-340. [CrossRef]

9. Rar, V.; Tkachev, S.; Tikunova, N. Genetic diversity of Anaplasma bacteria: Twenty years later. Infect. Genet. Evol. $2021,91,104833$. [CrossRef] 
10. Silaghi, C.; Santos, A.S.; Gomes, J.; Christova, I.; Matei, I.A.; Walder, G.; Domingos, A.; Bell-Sakyi, L.; Sprong, H.; von Loewenich, F.D.; et al. Guidelines for the Direct Detection of Anaplasma spp. in Diagnosis and Epidemiological Studies. Vector Borne Zoonotic Dis. 2017, 17, 12-22. [CrossRef]

11. Moraes-Filho, J.; Krawczak, F.S.; Costa, F.B.; Soares, J.F.; Labruna, M.B. Comparative Evaluation of the Vector Competence of Four South American Populations of the Rhipicephalus sanguineus Group for the Bacterium Ehrlichia canis, the Agent of Canine Monocytic Ehrlichiosis. PLoS ONE 2015, 10, e0139386. [CrossRef] [PubMed]

12. Ismail, N.; Bloch, K.C.; McBride, J.W. Human ehrlichiosis and anaplasmosis. Clin. Lab. Med. 2010, 30, 261-292. [CrossRef]

13. Rochlin, I.; Toledo, A. Emerging tick-borne pathogens of public health importance: A mini-review. J. Med. Microbiol. 2020, 69, 781-791. [CrossRef]

14. Kawahara, M.; Rikihisa, Y.; Isogai, E.; Takahashi, M.; Misumi, H.; Suto, C.; Shibata, S.; Zhang, C.; Tsuji, M. Ultrastructure and phylogenetic analysis of 'Candidatus Neoehrlichia mikurensis' in the family Anaplasmataceae, isolated from wild rats and found in Ixodes ovatus ticks. Int. J. Syst. Evol. Microbiol. 2004, 54 Pt 5, 1837-1843. [CrossRef]

15. Yabsley, M.J.; Murphy, S.M.; Luttrell, M.P.; Wilcox, B.R.; Howerth, E.W.; Munderloh, U.G. Characterization of 'Candidatus Neoehrlichia lotoris' (family Anaplasmataceae) from raccoons (Procyon lotor). Int. J. Syst. Evol. Microbiol. 2008, 58 Pt 12, $2794-2798$. [CrossRef]

16. Gofton, A.W.; Doggett, S.; Ratchford, A.; Ryan, U.; Irwin, P. Phylogenetic characterisation of two novel Anaplasmataceae from Australian Ixodes holocyclus ticks: 'Candidatus Neoehrlichia australis' and 'Candidatus Neoehrlichia arcana'. Int. J. Syst. Evol. Microbiol. 2016, 66, 4256-4261. [CrossRef] [PubMed]

17. Müller, A.; Monti, G.; Otth, C.; Sepúlveda, P.; Bittencourt, P.; Nachum-Biala, Y.; Gutiérrez, R.; Harrus, S. “Candidatus Neoehrlichia chilensis" sp. nov.: Molecular detection and characterization of a novel Anaplasmataceae in wild rodents from Valdivia, southern Chile. Transbound. Emerg. Dis. 2018, 65, 357-362. [CrossRef] [PubMed]

18. Brouqui, P.; Sanogo, Y.O.; Caruso, G.; Merola, F.; Raoult, D. Candidatus Ehrlichia walkerii: A new Ehrlichia detected in Ixodes ricinus tick collected from asymptomatic humans in Northern Italy. Ann. N. Y. Acad. Sci. 2003, 990, 134-140. [CrossRef] [PubMed]

19. Gofton, A.W.; Waudby, H.P.; Petit, S.; Greay, T.L.; Ryan, U.M.; Irwin, P.J. Detection and phylogenetic characterisation of novel Anaplasma and Ehrlichia species in Amblyomma triguttatum subsp. from four allopatric populations in Australia. Ticks Tick-Borne Dis. 2017, 8, 749-756. [CrossRef]

20. Rar, V.A.; Pukhovskaya, N.M.; Ryabchikova, E.I.; Vysochina, N.P.; Bakhmetyeva, S.V.; Zdanovskaia, N.I.; Ivanov, L.I.; Tikunova, N.V. Molecular-genetic and ultrastructural characteristics of 'Candidatus Ehrlichia khabarensis', a new member of the Ehrlichia genus. Ticks Tick-Borne Dis. 2015, 6, 658-667. [CrossRef]

21. Dahmani, M.; Davoust, B.; Tahir, D.; Raoult, D.; Fenollar, F.; Mediannikov, O. Molecular investigation and phylogeny of Anaplasmataceae species infecting domestic animals and ticks in Corsica, France. Parasites Vectors 2017, 10, 302. [CrossRef]

22. Gofton, A.W.; Loh, S.M.; Barbosa, A.D.; Paparini, A.; Gillett, A.; Macgregor, J.; Oskam, C.L.; Ryan, U.M.; Irwin, P.J. A novel Ehrlichia species in blood and Ixodes ornithorhynchi ticks from platypuses (Ornithorhynchus anatinus) in Queensland and Tasmania, Australia. Ticks Tick-Borne Dis. 2018, 9, 435-442. [CrossRef] [PubMed]

23. Muñoz-Leal, S.; Clemes, Y.S.; Lopes, M.G.; Acosta, I.; Serpa, M.; Mayorga, L.; Gennari, S.M.; González-Acuña, D.; Labruna, M.B. Novel Ehrlichia sp. detected in Magellanic penguins (Sphenicus magellanicus) and in the seabird tick Ixodes uriae from Magdalena Island, southern Chile. Ticks Tick-Borne Dis. 2019, 10, 101256. [CrossRef] [PubMed]

24. Kang, Y.J.; Diao, X.N.; Zhao, G.Y.; Chen, M.H.; Xiong, Y.; Shi, M.; Fu, W.M.; Guo, Y.J.; Pan, B.; Chen, X.P.; et al. Extensive diversity of Rickettsiales bacteria in two species of ticks from China and the evolution of the Rickettsiales. BMC Evol. Biol. 2014, 14, 167. [CrossRef] [PubMed]

25. Dahmani, M.; Davoust, B.; Rousseau, F.; Raoult, D.; Fenollar, F.; Mediannikov, O. Natural Anaplasmataceae infection in Rhipicephalus bursa ticks collected from sheep in the French Basque Country. Ticks Tick-Borne Dis. 2017, 8, 18-24. [CrossRef] [PubMed]

26. Guo, W.P.; Huang, B.; Zhao, Q.; Xu, G.; Liu, B.; Wang, Y.H.; Zhou, E.M. Human-pathogenic Anaplasma spp., and Rickettsia spp. in animals in Xi'an, China. PLoS Negl. Trop. Dis. 2018, 12, e0006916. [CrossRef] [PubMed]

27. Vanstreels, R.; Yabsley, M.J.; Parsons, N.J.; Swanepoel, L.; Pistorius, P.A. A novel candidate species of Anaplasma that infects avian erythrocytes. Parasites Vectors 2018, 11, 525. [CrossRef]

28. Dahmani, M.; Davoust, B.; Sambou, M.; Bassene, H.; Scandola, P.; Ameur, T.; Raoult, D.; Fenollar, F.; Mediannikov, O. Molecular investigation and phylogeny of species of the Anaplasmataceae infecting animals and ticks in Senegal. Parasites Vectors 2019, 12, 495. [CrossRef]

29. Calchi, A.C.; Vultão, J.G.; Alves, M.H.; Yogui, D.R.; Desbiez, A.; De Santi, M.; Santana, M.S.; da Silva, T.; Werther, K.; Teixeira, M.; et al. Ehrlichia spp. and Anaplasma spp. in Xenarthra mammals from Brazil, with evidence of novel 'Candidatus Anaplasma spp.'. Sci. Rep. 2020, 10, 12615. [CrossRef]

30. Greiman, S.E.; Tkach, M.; Vaughan, J.A.; Tkach, V.V. Laboratory maintenance of the bacterial endosymbiont, Neorickettsia sp., through the life cycle of a digenean, Plagiorchis elegans. Exp. Parasitol. 2015, 157, 78-83. [CrossRef]

31. Teymournejad, O.; Lin, M.; Bekebrede, H.; Kamr, A.; Toribio, R.E.; Arroyo, L.G.; Baird, J.D.; Rikihisa, Y. Isolation and Molecular Analysis of a Novel Neorickettsia Species That Causes Potomac Horse Fever. mBio 2020, 11, e03429-19. [CrossRef] 
32. Paulino, P.G.; Almosny, N.; Oliveira, R.; Viscardi, V.; Müller, A.; Guimarães, A.; Baldani, C.; da Silva, C.; Peckle, M.; Massard, C.; et al. Detection of Neorickettsia risticii, the agent of Potomac horse fever, in horses from Rio de Janeiro, Brazil. Sci. Rep. 2020, 10, 7208. [CrossRef]

33. Dutra, F.; Schuch, L.D.F.; Delucchi, E.; Curcio, B.R.; Coimbra, H.S.; Raffi, M.B.; Dellagostin, O.; Riet-Correa, F. Equine monocytic Ehrlichiosis (Potomac Horse Fever) in horses in Uruguay and southern Brazil. J. Vet. Diagn. Investig. 2001, 13, 433-437. [CrossRef] [PubMed]

34. Coimbra, H.S.; Fernandes, C.G.; Soares, M.P.; Meireles, M.C.A.; Radamés, R.; Schuch, L.F.D. Equine monocytic Ehrlichiosis in Rio Grande do Sul: Clinical, pathological and epidemiological aspects. Pesqui. Veterinária Bras. 2006, 26, 97-101. [CrossRef]

35. Afonso, E.; Goydadin, A.C. Molecular detection of Anaplasma phagocytophilum DNA in the lesser horseshoe bat (Rhinolophus hipposideros) guano. Epidemiol. Infect. 2018, 146, 1253-1258. [CrossRef] [PubMed]

36. Hornok, S.; Szoke, K.; Meli, M.L.; Sándor, A.D.; Görföl, T.; Estók, P.; Wang, Y.; Tu, V.T.; Kováts, D.; Boldogh, S.A.; et al. Molecular detection of vector-borne bacteria in bat ticks (Acari: Ixodidae, Argasidae) from eight countries of the Old and New Worlds 06 Biological Sciences 0604 Genetics. Parasites Vectors 2019, 12, 1-7. [CrossRef] [PubMed]

37. Zabashta, M.V.; Orlova, M.V.; Pichurina, N.L.; Khametova, A.P.; Romanova, L.V.; Borodina, T.N.; Zabashta, A.V. Participation of Bats (Chiroptera, Mammalia) and Their Ectoparasites in Circulation of Pathogens of Natural Focal Infections in the South of Russia. Entmol. Rev. 2019, 99, 513-521. [CrossRef]

38. Socolovschi, C.; Kernif, T.; Raoult, D.; Parola, P. Borrelia, Rickettsia, and Ehrlichia species in bat ticks, France, 2010. Emerg. Infect. Dis. 2012, 18, 1966-1975. [CrossRef] [PubMed]

39. Reeves, W.K.; Beck, J.; Orlova, M.V.; Daly, J.L.; Pippin, K.; Revan, F.; Loftis, A.D. Ecology of Bats, Their Ectoparasites, and Associated Pathogens on Saint Kitts Island. J. Med. Entomol. 2016, 53, 1218-1225. [CrossRef]

40. Lv, J.; Fernández de Marco, M.; Goharriz, H.; Phipps, L.P.; McElhinney, L.M.; Hernández-Triana, L.M.; Wu, S.; Lin, X.; Fooks, A.R.; Johnson, N. Detection of tick-borne bacteria and babesia with zoonotic potential in Argas (Carios) vespertilionis (Latreille, 1802) ticks from British bats. Sci. Rep. 2018, 8, 1865. [CrossRef] [PubMed]

41. Pusterla, N.; Johnson, E.M.; Chae, J.S.; Madigan, J.E. Digenetic trematodes, Acanthatrium sp. and Lecithodendrium sp., as vectors of Neorickettsia risticii, the agent of Potomac horse fever. J. Helminthol. 2003, 77, 335-339. [CrossRef] [PubMed]

42. Gibson, K.E.; Rikihisa, Y.; Zhang, C.; Martin, C. Neorickettsia risticii is vertically transmitted in the trematode Acanthatrium oregonense and Horizontally transmitted to bats. Environ. Microbiol. 2005, 2, 203-212. [CrossRef]

43. Cicuttin, G.L.; Boeri, E.J.; Beltrán, F.J.; Dohmen, F.E.G. Molecular detection of Neorickettsia risticii in Brazilian free-tailed bats (Tadarida brasiliensis) from Buenos Aires, Argentina. Pesqui. Veterinária Bras. 2013, 33, 648-650. [CrossRef]

44. Cicuttin, G.L.; De Salvo, M.N.; La Rosa, I.; Dohmen, F.E.G. Neorickettsia risticii, Rickettsia sp. and Bartonella sp. in Tadarida brasiliensis bats from Buenos Aires, Argentina. Comp. Immunol. Microbiol. Infect. Dis. 2017, 52, 1-5. [CrossRef] [PubMed]

45. Greiman, S.E.; Vaughan, J.A.; Elmahy, R.; Adisakwattana, P.; Van Ha, N.; Fayton, T.J.; Khalil, A.I.; Tkach, V.V. Real-time PCR detection and phylogenetic relationships of Neorickettsia spp. in digeneans from Egypt, Philippines, Thailand, Vietnam and the United States. Parasitol. Int. 2017, 66, 1003-1007. [CrossRef] [PubMed]

46. Hornok, S.; Szőke, K.; Estók, P.; Krawczyk, A.; Haarsma, A.J.; Kováts, D.; Boldogh, S.A.; Morandini, P.; Szekeres, S.; Takács, N.; et al. Assessing bat droppings and predatory bird pellets for vector-borne bacteria: Molecular evidence of batassociated Neorickettsia sp. in Europe. Antonie Van Leeuwenhoek Int. J. Gen. Mol. Microbiol. 2018, 111, 1707-1717. [CrossRef] [PubMed]

47. Maurin, M.; Raoult, D. Q fever. Clin. Microbiol. Rev. 1999, 12, 518-553. [CrossRef] [PubMed]

48. Eldin, C.; Mélenotte, C.; Mediannikov, O.; Ghigo, E.; Million, M.; Edouard, S.; Mege, J.L.; Maurin, M.; Raoult, D. From Q Fever to Coxiella burnetii Infection: A Paradigm Change. Clin. Microbiol. Rev. 2017, 30, 115-190. [CrossRef]

49. Damasceno, I.; Guerra, R.C. Coxiella burnetii e a febre Q no Brasil, uma questão de saúde pública [Coxiella burnetii and Q fever in Brazil: A public health issue]. Cienc. Saude Coletiva 2018, 23, 4231-4239. [CrossRef]

50. Angelakis, E.; Raoult, D. Q Fever. Vet. Microbiol. 2010, 140, 297-309. [CrossRef]

51. Leulmi, H.; Aouadi, A.; Bitam, I.; Bessas, A.; Benakhla, A.; Raoult, D.; Parola, P. Detection of Bartonella tamiae, Coxiella burnetii and rickettsiae in arthropods and tissues from wild and domestic animals in northeastern Algeria. Parasites Vectors 2016, 9, 27. [CrossRef]

52. Dietrich, M.; Kearney, T.; Seamark, E.C.; Markotter, W. The excreted microbiota of bats: Evidence of niche specialisation based on multiple body habitats. FEMS Microbiol. Lett. 2017, 364, fnw284. [CrossRef]

53. Ferreira, M.S.; Guterres, A.; Rozental, T.; Novaes, R.L.M.; Vilar, E.M.; De Oliveira, R.C.; Fernandes, J.; Forneas, D.; Junior, A.A.; Brandão, M.L.; et al. Coxiella and Bartonella spp. In bats (Chiroptera) captured in the Brazilian Atlantic Forest biome. BMC Vet. Res. 2018, 14, 279. [CrossRef] [PubMed]

54. Szubert-Kruszyńska, A.; Stańczak, J.; Cieniuch, S.; Podsiadły, E.; Postawa, T.; Michalik, J. Bartonella and Rickettsia Infections in Haematophagous Spinturnix myoti Mites (Acari: Mesostigmata) and their Bat Host, Myotis myotis (Yangochiroptera: Vespertilionidae), from Poland. Microb. Ecol. 2019, 77, 759-768. [CrossRef] [PubMed]

55. Mongruel, A.C.B.; Benevenute, J.L.; Ikeda, P.; André, M.R.; Machado, R.Z.; Carrasco, A.O.T.; Seki, M.C. Detection of Anaplasma sp. Phylogenetically related to A. phagocytophilum in a free-living bird in Brazil. Rev. Bras. De Parasitol. Vet. 2017, 26, 505-510. [CrossRef]

56. Allsopp, B.A. Heartwater-Ehrlichia ruminantium infection. Rev. Sci. Et Tech. 2015, 34, 557-568. [CrossRef] 
57. Widmer, C.E.; Azevedo, F.C.; Almeida, A.P.; Ferreira, F.; Labruna, M.B. Tick-borne bacteria in free-living jaguars (Panthera onca) in Pantanal, Brazil. Vector Borne Zoonotic Dis. 2011, 11, 1001-1005. [CrossRef] [PubMed]

58. Almeida, A.P.; Souza, T.D.; Marcili, A.; Labruna, M.B. Novel Ehrlichia and Hepatozoon agents infecting the crab-eating fox (Cerdocyon thous) in southeastern Brazil. J. Med. Entomol. 2013, 50, 640-646. [CrossRef] [PubMed]

59. Cruz, A.C.; Zweygarth, E.; Ribeiro, M.F.; da Silveira, J.A.; de la Fuente, J.; Grubhoffer, L.; Valdés, J.J.; Passos, L.M. New species of Ehrlichia isolated from Rhipicephalus (Boophilus) microplus shows an ortholog of the E. canis major immunogenic glycoprotein gp36 with a new sequence of tandem repeats. Parasites Vectors 2012, 5, 291. [CrossRef]

60. Aguiar, D.M.; Araujo, J.P., Jr.; Nakazato, L.; Bard, E.; Cabezas-Cruz, A. Complete Genome Sequence of an Ehrlichia minasensis Strain Isolated from Cattle. Microbiol. Resour. Announc. 2019, 8, e00161-19. [CrossRef]

61. Aguiar, D.M.; Ziliani, T.F.; Zhang, X.; Melo, A.L.; Braga, I.A.; Witter, R.; Freitas, L.C.; Rondelli, A.L.; Luis, M.A.; Sorte, E.C.; et al. A novel Ehrlichia genotype strain distinguished by the TRP36 gene naturally infects cattle in Brazil and causes clinical manifestations associated with ehrlichiosis. Ticks Tick-Borne Dis. 2014, 5, 537-544. [CrossRef]

62. Benevenute, J.L.; Dumler, J.S.; Ogrzewalska, M.; Roque, A.; Mello, V.; de Sousa, K.; Gonçalves, L.R.; D’Andrea, P.S.; de Sampaio Lemos, E.R.; Machado, R.Z.; et al. Assessment of a quantitative 5' nuclease real-time polymerase chain reaction using groEL gene for Ehrlichia and Anaplasma species in rodents in Brazil. Ticks Tick-Borne Dis. 2017, 8, 646-656. [CrossRef]

63. De Sousa, K.; Calchi, A.C.; Herrera, H.M.; Dumler, J.S.; Barros-Battesti, D.M.; Machado, R.Z.; André, M.R. Anaplasmataceae agents among wild mammals and ectoparasites in Brazil. Epidemiol. Infect. 2017, 145, 3424-3437. [CrossRef]

64. Holland, C.; Weiss, E.; Burgdorfer, W.; Cole, A.I.; Kakoma, I. Ehrlichia risticii sp. nov.: Etiological Agent of Equine Monocytic Ehrlichiosis (Synonym, Potomac Horse Fever). Int. J. Syst. Evol. Microbiol. 1985, 35, 524-526. [CrossRef]

65. Barlough, J.E.; Reubel, G.H.; Madigan, J.E.; Vredevoe, L.K.; Miller, P.E.; Rikihisa, Y. Detection of Ehrlichia risticii, the agent of Potomac horse fever, in freshwater stream snails (Pleuroceridae: Juga spp.) from northern California. Appl. Environ. Microbiol. 1998, 4, 2888-2893. [CrossRef] [PubMed]

66. Vaughan, J.A.; Tkach, V.V.; Greiman, S.E. Chapter 3-Neorickettsial Endosymbionts of the Digenea: Diversity, Transmission and Distribution. Adv. Parasitol. 2012, 79, 253-297. [CrossRef] [PubMed]

67. Baldridge, G.D.; Scoles, G.A.; Burkhardt, N.Y.; Schloeder, B.; Kurtti, T.J.; Munderloh, U.G. Transovarial transmission of Francisellalike endosymbionts and Anaplasma phagocytophilum variants in Dermacentor albipictus (Acari: Ixodidae). J. Med. Entomol. 2009, 46, 625-632. [CrossRef] [PubMed]

68. Braga, M.; Gonçalves, L.R.; Silva, T.; Costa, F.B.; Pereira, J.G.; Santos, L.; Carvalho Neta, A.V.; Arruda, R.; Mesquita, E.; Chaves, D.P.; et al. Occurrence of Bartonella genotypes in bats and associated Streblidae flies from Maranhão state, northeastern Brazil. Rev. Bras. De Parasitol. Vet. 2020, 29, e014420. [CrossRef]

69. Müller, A.; Sepúlveda, P.; Di Cataldo, S.; Cevidanes, A.; Lisón, F.; Millán, J. Molecular investigation of zoonotic intracellular bacteria in Chilean bats. Comp. Immunol. Microbiol. Infect. Dis. 2020, 73, 101541. [CrossRef]

70. Costa, P.S.; Brigatte, M.E.; Greco, D.B. Questing one Brazilian query: Reporting 16 cases of Q fever from Minas Gerais, Brazil. Rev. Do Inst. De Med. Trop. De Sao Paulo 2006, 48, 5-9. [CrossRef] [PubMed]

71. Brenner, A.E.; Muñoz-Leal, S.; Sachan, M.; Labruna, M.B.; Raghavan, R. Coxiella burnetii and Related Tick Endosymbionts Evolved from Pathogenic Ancestors. Genome Biol. Evol. 2021, 13, evab108. [CrossRef]

72. Lemos, E.R.; Rozental, T.; Mares-Guia, M.A.; Almeida, D.N.; Moreira, N.; Silva, R.G.; Barreira, J.D.; Lamas, C.C.; Favacho, A.R.; Damasco, P.V. Q fever as a cause of fever of unknown origin and thrombocytosis: First molecular evidence of Coxiella burnetii in Brazil. Vector Borne Zoonotic Dis. 2011, 11, 85-87. [CrossRef]

73. Lamas, C.C.; Fournier, P.E.; Zappa, M.; Brandão, T.J.; Januário-da-Silva, C.A.; Correia, M.G.; Barbosa, G.I.; Golebiovski, W.F.; Weksler, C.; Lepidi, H.; et al. Diagnosis of blood culture-negative endocarditis and clinical comparison between blood culturenegative and blood culture-positive cases. Infection 2016, 44, 459-466. [CrossRef]

74. Ikeda, P.; Menezes, T.R.; Torres, J.M.; de Oliveira, C.E.; Lourenço, E.C.; Herrera, H.M.; Machado, R.Z.; André, M.R. First molecular detection of piroplasmids in non-hematophagous bats from Brazil, with evidence of putative novel species. Parasitol. Res. 2021, 120, 301-310. [CrossRef]

75. Birkenheuer, A.J.; Levy, M.G.; Breitschwerdt, E.B. Development and evaluation of a seminested PCR for detection and differentiation of Babesia gibsoni (Asian genotype) and B. canis DNA in canine blood samples. J. Clin. Microbiol. 2003, 41, $4172-4177$. [CrossRef] [PubMed]

76. Folmer, O.; Black, M.; Hoeh, W.; Lutz, R.; Vrijenhoek, R. DNA primers for amplification of mitochondrial cytochrome c oxidase subunit I from diverse metazoan invertebrates. Mol. Mar. Biol. Biotechnol. 1994, 3, 294-299. [PubMed]

77. Mangold, A.J.; Bargues, M.D.; Mas-Coma, S. Mitochondrial 16S rDNA sequences and phylogenetic relationships of species of Rhipicephalus and other tick genera among Metastriata (Acari: Ixodidae). Parasitol. Res. 1998, 84, 478-484. [CrossRef] [PubMed]

78. Massung, R.F.; Slater, K.; Owens, J.H.; Nicholson, W.L.; Mather, T.N.; Solberg, V.B.; Olson, J.G. Nested PCR assay for detection of granulocytic ehrlichiae. J. Clin. Microbiol. 1998, 36, 1090-1095. [CrossRef]

79. Doyle, C.K.; Labruna, M.B.; Breitschwerdt, E.B.; Tang, Y.W.; Corstvet, R.E.; Hegarty, B.C.; Bloch, K.C.; Li, P.; Walker, D.H.; McBride, J.W. Detection of medically important Ehrlichia by quantitative multicolor TaqMan real-time polymerase chain reaction of the dsb gene. J. Mol. Diagn. JMD 2005, 7, 504-510. [CrossRef]

80. Reller, M.E.; Dumler, J.S. Development and Clinical Validation of a Multiplex Real-Time Quantitative PCR Assay for Human Infection by Anaplasma phagocytophilum and Ehrlichia chaffeensis. Trop. Med. Infect. Dis. 2018, 3, 14. [CrossRef] [PubMed] 
81. Drazenovich, N.; Foley, J.; Brown, R.N. Use of real-time quantitative PCR targeting the $m s p 2$ protein gene to identify cryptic Anaplasma phagocytophilum infections in wildlife and domestic animals. Vector Borne Zoonotic Dis. 2006, 6, 83-90. [CrossRef] [PubMed]

82. Sumner, J.W.; Nicholson, W.L.; Massung, R.F. PCR amplification and comparison of nucleotide sequences from the groESL heat shock operon of Ehrlichia species. J. Clin. Microbiol. 1997, 35, 2087-2092. [CrossRef] [PubMed]

83. O'Nion, V.L.; Montilla, H.J.; Qurollo, B.A.; Maggi, R.G.; Hegarty, B.C.; Tornquist, S.J.; Breitschwerdt, E.B. Potentially novel Ehrlichia species in horses, Nicaragua. Emerg. Infect. Dis. 2015, 21, 335-338. [CrossRef] [PubMed]

84. Inayoshi, M.; Naitou, H.; Kawamori, F.; Masuzawa, T.; Ohashi, N. Characterization of Ehrlichia species from Ixodes ovatus ticks at the foot of Mt. Fuji, Japan. Microbiol. Immunol. 2004, 48, 737-745. [CrossRef] [PubMed]

85. Rejmanek, D.; Bradburd, G.; Foley, J. Molecular characterization reveals distinct genospecies of Anaplasma phagocytophilum from diverse North American hosts. J. Med. Microbiol. 2012, 61 Pt 2, 204-212. [CrossRef] [PubMed]

86. Chae, J.S.; Kim, E.H.; Kim, M.S.; Kim, M.J.; Cho, Y.H.; Park, B.K. Prevalence and sequence analyses of Neorickettsia Risticii. Ann. N. Y. Acad. Sci. 2003, 990, 248-256. [CrossRef]

87. Kanter, M.; Mott, J.; Ohashi, N.; Fried, B.; Reed, S.; Lin, Y.C.; Rikihisa, Y. Analysis of 16S rRNA and 51-kilodalton antigen gene and transmission in mice of Ehrlichia risticii in virgulate trematodes from Elimia livescens snails in Ohio. J. Clin. Microbiol. 2000, 38, 3349-3358. [CrossRef]

88. Gibson, K.E.; Pastenkos, G.; Moesta, S.; Rikihisa, Y. Neorickettsia risticii surface-exposed proteins: Proteomics identification, recognition by naturally-infected horses, and strain variations. Vet. Res. 2011, 42, 71. [CrossRef]

89. Klee, S.R.; Tyczka, J.; Ellerbrok, H.; Franz, T.; Linke, S.; Baljer, G.; Appel, B. Highly sensitive real-time PCR for specific detection and quantification of Coxiella burnetii. BMC Microbiol. 2006, 6, 2. [CrossRef] [PubMed]

90. Hall, T.A. BioEdit: A user-friendly biological sequence alignment editor and analysis program for Windows 95/98/NT. Nucleic Acids Symp. Ser. 1999, 41, 95-98.

91. Altschul, S.F.; Gish, W.; Miller, W.; Myers, E.W.; Lipman, D.J. Basic local alignment search tool. J. Mol. Biol. 1990, 215 , 403-410. [CrossRef]

92. Benson, D.A.; Cavanaugh, M.; Clark, K.; Karsch-Mizrachi, I.; Ostell, J.; Pruitt, K.D.; Sayers, E.W. GenBank. Nucleic Acids Res. 2018, 46, D41-D47. [CrossRef] [PubMed]

93. Thompson, J.D.; Higgins, D.G.; Gibson, T.J. CLUSTAL W: Improving the sensitivity of progressive multiple sequence alignment through sequence weighting, position-specific gap penalties and weight matrix choice. Nucleic Acids Res. 1994, 22, 4673-4680. [CrossRef]

94. Kalyaanamoorthy, S.; Minh, B.Q.; Wong, T.; von Haeseler, A.; Jermiin, L.S. ModelFinder: Fast model selection for accurate phylogenetic estimates. Nat. Methods 2017, 14, 587-589. [CrossRef] [PubMed]

95. Nguyen, L.T.; Schmidt, H.A.; von Haeseler, A.; Minh, B.Q. IQ-TREE: A fast and effective stochastic algorithm for estimating maximum-likelihood phylogenies. Mol. Biol. Evol. 2015, 32, 268-274. [CrossRef] [PubMed]

96. Hoang, D.T.; Chernomor, O.; von Haeseler, A.; Minh, B.Q.; Vinh, L.S. UFBoot2: Improving the Ultrafast Bootstrap Approximation. Mol. Biol. Evol. 2018, 35, 518-522. [CrossRef] [PubMed]

97. Stöver, B.C.; Müller, K.F. TreeGraph 2: Combining and visualizing evidence from different phylogenetic analyses. BMC Bioinform. 2010, 11, 7. [CrossRef] [PubMed] 